\title{
LARGE EPIBENTHIC INVERTEBRATES IN THE BRAS D'OR LAKES
}

\author{
M. JOHN TREMBLAY \\ Invertebrate Fisheries Division, Fisheries and Oceans Canada \\ Bedford Institute of Oceanography, P.O. Box 1006 \\ Dartmouth, N.S. Canada B2Y4A2
}

\begin{abstract}
The distribution of large epibenthic invertebrates (lobster and crabs, bivalve molluscs and echinoderms) in the Bras d'Or Lakes is reviewed, and possible limiting factors are identified. The review is based on published and unpublished studies, including recent trawl surveys directed at fish, and trapping studies directed at American lobster Homarus americanus and green crab Carcinus maenas. The reduced salinities within the Lakes probably limit the distribution of several species (rock crab Cancer irroratus, sea scallop Placopecten magellanicus and possibly American lobster), particularly during the more sensitive larval period. Lobsters and eastern oysters Crassostrea virginica serve to illustrate the multiple factors limiting epibenthic invertebrate distribution within the Bras d'Or Lakes. Lobsters are less abundant within the Bras d'Or Lakes than on the outer coast of Cape Breton Island. Possible reasons are the reduced salinity and limited cobble bottom substrate in the Bras d'Or Lakes, coupled with low food availability and low egg production. Low egg production may be the result of overfishing of lobsters in the past. The life history and physiology of the eastern oyster appears to be well suited to the areas of the Lakes with warm summer temperatures. The oyster populations in the Bras d'Or Lakes are limited by natural predators (e.g. starfish and green crab), competitors (e.g. blue mussel Mytilus edulis and M. trossulus), and overfishing. The green crab, a new arrival to the Bras d'Or Lakes, will likely have negative effects on bivalves such as oysters, but the overall effect of green crab on the Bras d'Or Lakes food web is difficult to predict. Recent trawl surveys indicate both sea urchins Strongylocentrotus droebachiensis and starfish are present in considerable abundance, but little is known about their ecological roles in the Bras d'Or Lakes.
\end{abstract}

La distribution des grands invertébrés épibenthique (les homards et les crabes, les mollusques bivalves et les échinodermes) dans les lacs du Bras d'Or est examinée et les coefficients possiblement limitatifs sont identifies. La revue est basée sur des études publiées et non-publiées englobant les plus récentes études sur la pêche au chalut dirigées vers les poissons et les études sur la pêche aux casiers dirigées vers les homards américains Homarus americanus et les crabes verts Carcinus maenas. Salinités réduites dans les lacs du Bras d'Or limitent probablement la distribution de quelques espèces crabes roches Cancer irroratus, pétoncle géant Placopecten magellanicus et possiblement le homard américain, en particulier, pendent l'époque sensible du larvaire. Les homards et les huîtres de l'Est Crossostrea virginica montrent plusieurs facteurs coefficients limitatifs de la distribution des invertébrés épibenthique dan les lacs du Bras d'Or. Les homards sont moins abondants ici que sur la côte extérieure de L'Ille du Cap Breton. Des explications possibles sont la réduction de l'eau saline du pavé rond limite dans le substratum de lacs, ainsi que la pauvre disponibilité de mangé et la production basse des œufs. Cette dernière est peut-être le résultat d'un trop grand prise de homards au passè. L'histoire et la physiologie des huîtres semblent être bien adaptés aux lieux des lacs de Bras d'Or, qui ont des temperatures chaudes dan l'été. La population des huîtres dans les lacs est limitée par des proies natures ( ie étoiles de mer et les crabes verts) compétiteurs ( ie. Moules bleus Mytilus edulis et $M$. trossulus) et une trop grande prise de poissons. Le crabe vert, une arrivée nouvelle dans les lacs du Bras d'Or va sans doute avoir des impacts négatifs sur les bivalues comme les huîtres, mais leurs impacts en general sur la chaîne nutritive est difficile à prédire. Les études les plus recents sur la pêche au chalut montrent qu'il y a un grand nombre d'oursins de mer Strongylocentrotus droebachiensis et des étoiles de mer, mais on ne connait pas quel est leur rôle écologique dans les lacs du Bras d'Or.

\section{Introduction}

Epibenthic invertebrates live on the surface of the seabed. Most species belong to taxonomic groups such as crustaceans (e.g. lobster Homarus americanus, rock crab Cancer irroratus and green crab Carcinus maenas - Fig 1), bivalve molluscs (e.g. eastern oyster Crassostrea virginica, blue mussel Mytilus edulis - Fig 1), gastropod molluscs 
(e.g. whelks, periwinkles) or echinoderms (e.g. sea urchin Strongylocentrotus droebachiensis, starfish). The term shellfish is reserved for those groups that are edible, including species such as oysters and lobsters that are of major economic and cultural importance. Infaunal invertebrates live within the sediment and include worms such as polychaetes and nematodes, small crustaceans such as amphipods and isopods, and several lesser known phyla. This paper reviews the limited information available on the distribution and abundance of some of the larger epibenthic invertebrates in the Bras d'Or Lakes. There has been no single comprehensive study of invertebrate distribution within the Lakes, but by drawing from published and unpublished studies, as well as traditional and anecdotal knowledge, it is possible to document some major patterns. To better understand the distribution of some key species, important features of the Bras d'Or Lakes environment are reviewed, together with invertebrate life histories and environmental relationships.
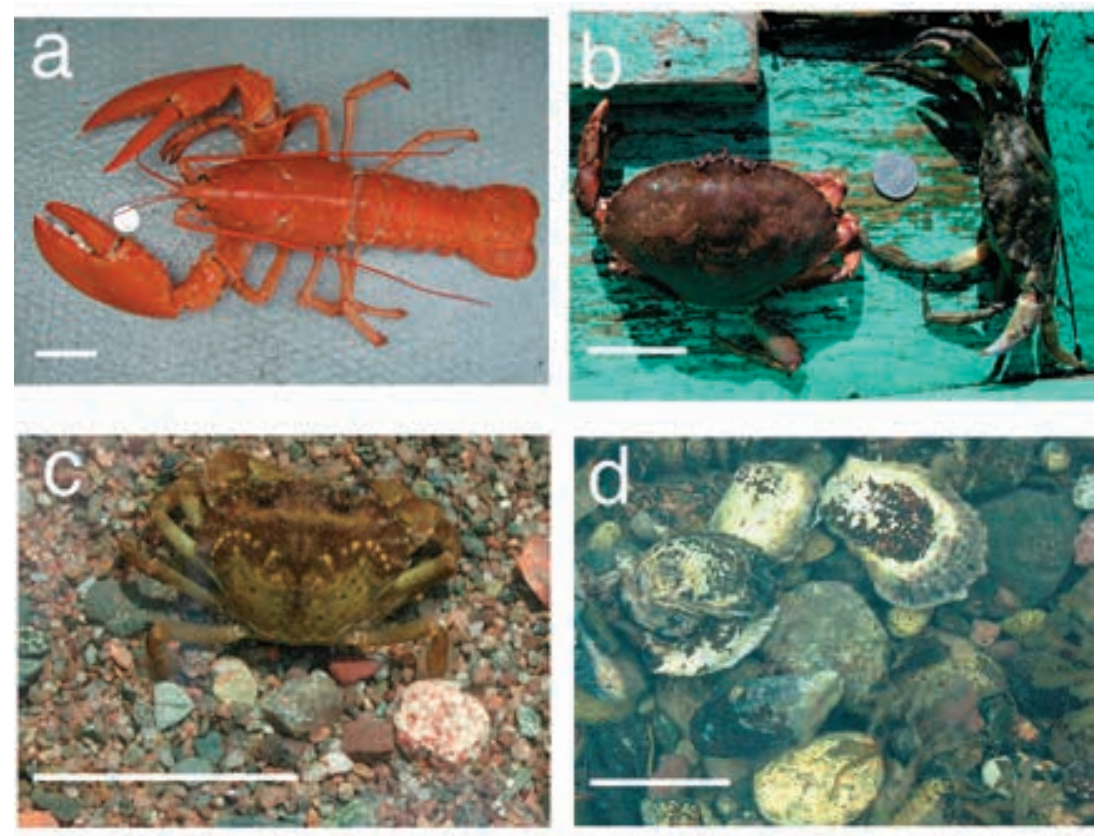

Fig 1 Photographs of some common epibenthic invertebrates found in the Bras d'Or Lakes. (a) A live orange lobster (a colourmorph) trapped in the Great Bras d'Or Channel, (b) male rock and green crabs captured in the same trap, (c) a green crab in a few cm of water off Benacadie Point, Outer East Bay (d) oysters and a blue mussel off Benacadie Point. White scale bar is $5 \mathrm{~cm}$.

\section{The Physical and Biological Setting}

Oceanography Key oceanographic features of the Bras d'Or Lakes (Fig 2) relevant to the distribution of epibenthic invertebrates include their semi-enclosed nature and freshwater input, their wide-ranging temperatures, and their low tidal amplitudes 
(Petrie and Bugden, 2002). Exchange with the more oceanic waters of Sydney Bight is limited by the narrow and shallow entrances to the Lakes. This limited exchange, coupled with the freshwater input, leads to reduced salinity, which is apparent in plots of salinity frequency for 3 areas within the Lakes, and in Sydney Bight (Fig 3). Salinities decrease with distance from Sydney Bight, with most observations in Bras d'Or Lake between 21 and 23. By comparison salinities in Sydney Bight are typically between 29 and 32 (Fig 3). Throughout the Bras d'Or Lakes salinities are lower in the 0-10 m depth interval than in the 10-50 m depth interval and in the upper metre of the

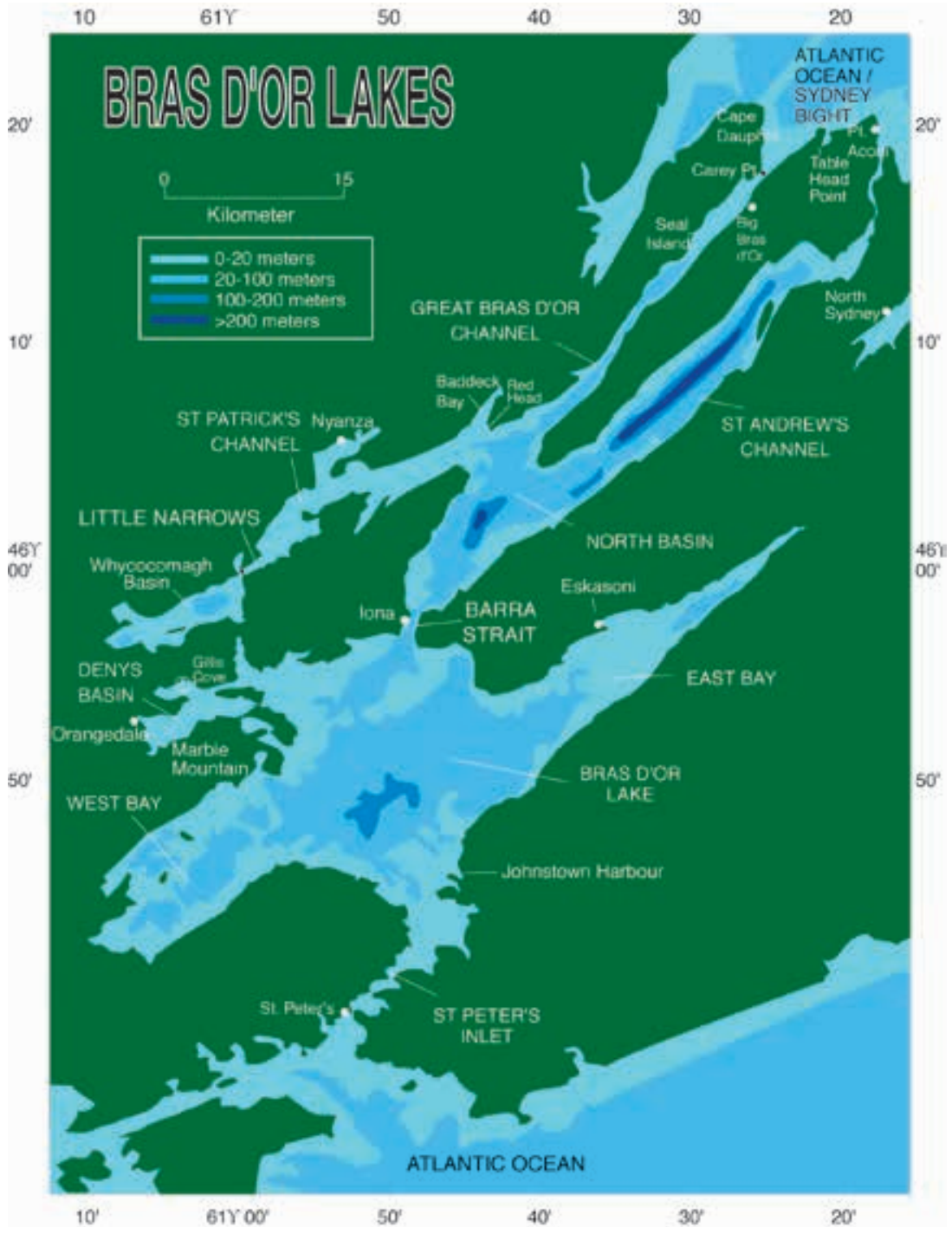

Fig 2 Map of the Bras d'Or Lakes showing place names used in text 

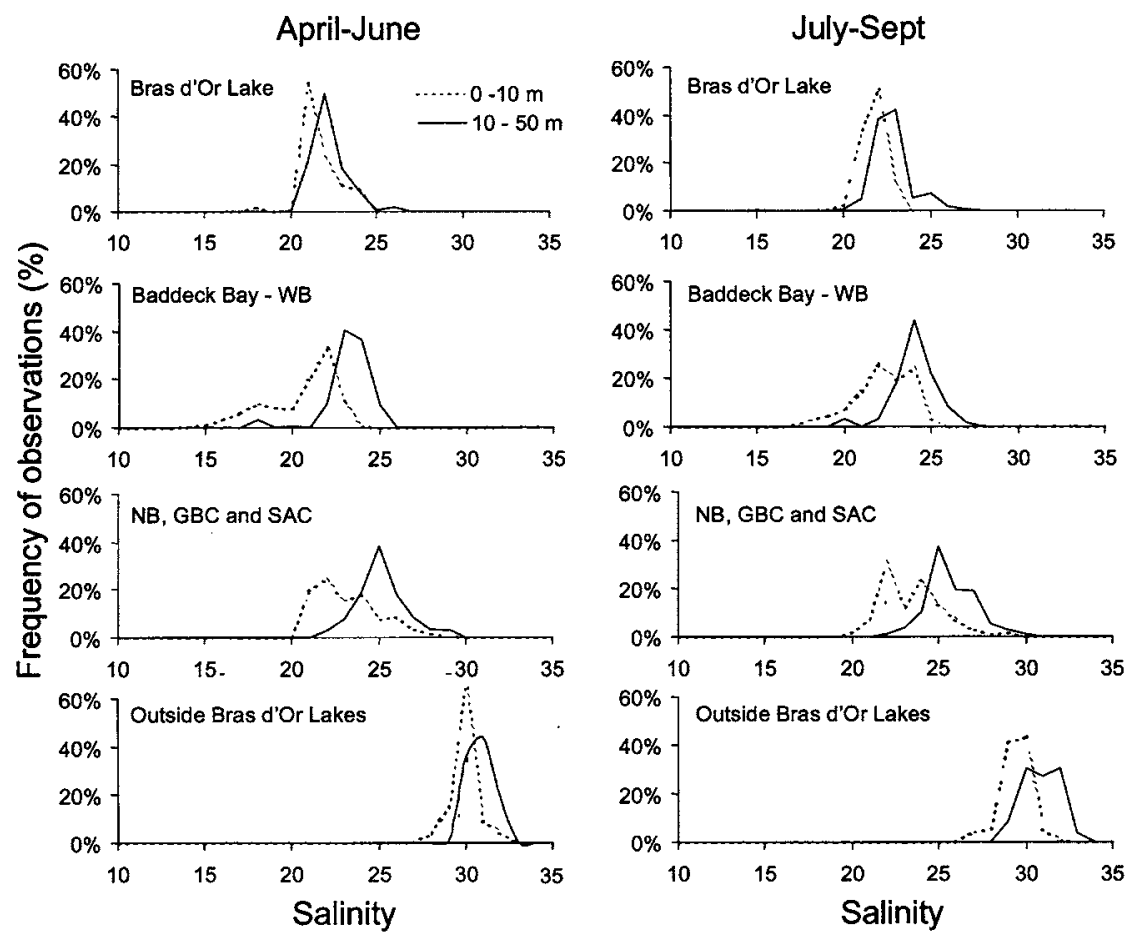

Fig 3 Frequency distribution of salinity measurements taken inside and outside the Bras d'Or Lakes. Oceanic salinities are > 30; freshwater is 0. Data are from April-June and July-Sept. Bras d'Or Lake includes West and East Bays, Baddeck Bay - WB (Whycocomagh Basin) includes Baddeck Bay, St. Patrick's Channel and Wycocomagh Basin; NB, GBC and SAC is North Basin, Great Bras d'Or Channel and Saint Andrew's Channel; Outside Bras d'Or Lakes is the area extending approximately $30 \mathrm{~km}$ north of Cape Dauphin and Point Aconi and $60 \mathrm{~km}$ to the east.

Wycocomogh and Denys Basins maybe 5 after rainfall (Petrie, 2001). There is also a seasonal difference in salinity, with lower salinities in spring compared to summer.

Bottom temperatures can range from $0^{\circ} \mathrm{C}$ to more than $20^{\circ} \mathrm{C}$ in some shallow embayments but at depths greater than $60 \mathrm{~m}$, temperature is below $6^{\circ} \mathrm{C}$ year-round (Petrie and Bugden, 2002). Ice cover can be extensive in some years. The small tides in the Lakes result in a negligible intertidal zone. In Sydney Bight the difference between low and high tides is 1-2 $\mathrm{m}$, but this is reduced by half in the Great Bras d'Or Channel and to about $10 \mathrm{~cm}$ in Bras d'Or Lake.

Bottom type The composition of the epibenthos is strongly affected by bottom type. Vilks (1967) analyzed the sediment obtained in samples from an Ekman dredge (box-type sampler with spring loaded jaws) deployed at some 196 stations throughout the Bras d'Or Lakes. A plot of the frequency of different grain sizes in different parts of the Lakes shows that most sediment is comprised of silt with smaller proportions of sand, 
gravel and boulder (Fig 4). The boulder category was not what we typically think of as boulders since the minimum size was just $16 \mathrm{~mm}$ diameter. The Great Bras d'Or Channel, North Basin and St. Andrew's Channel had a lower percentage of smaller grain sizes than Denys Basin and St. Patrick's Channel. Depth and current were important factors in determining sediment size, since fine sediments rich in organic matter were characteristic of the restricted deep regions of Wycocomagh Bay and St. Andrew's Channel, the relatively shallow but protected regions of St. Patrick's

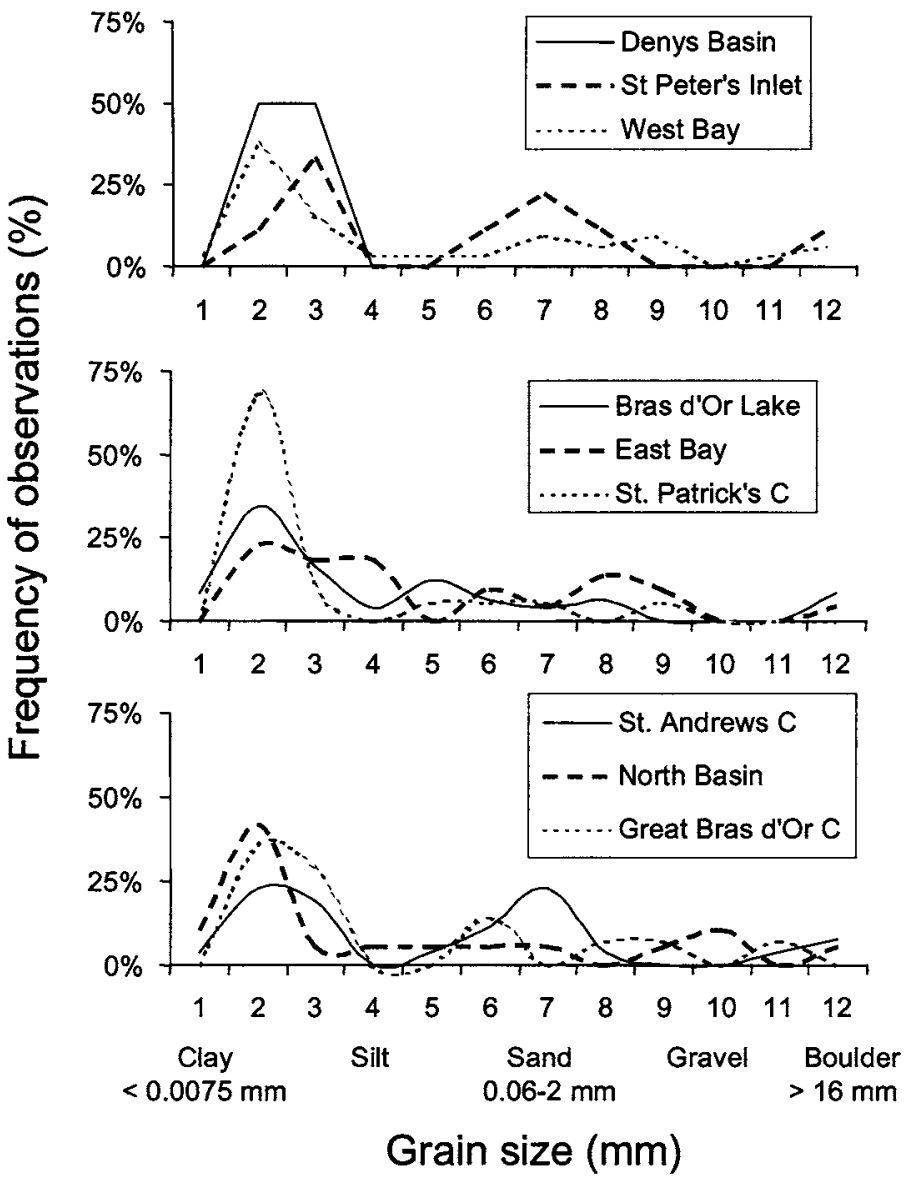

Fig 4 Frequency distribution of grain size measurements from different parts of the Bras d'Or Lakes. Data were obtained with an Ekman dredge sampler by Vilks (1967). The 12 categories from Vilks (1967) are of increasing size corresponding to the different mixtures of clay, silt, sand, gravel and boulder. Some categories (e.g. clay-sand) were combined with adjacent categories if the number of observations was $<3$. 
Channel, and the central deep areas of Bras d'Or Lake. In the Great Bras d'Or Channel and the more shallow regions of the Lakes, sediments were coarser (Vilks, 1967).

Shoreline Vegetation Different types of shoreline vegetation are associated with different epibenthic communities. A study of the marine flora of the shorelines of Bras d'Or Lakes (McLachlan and Edelstein, 1971) reported that the single most abundant
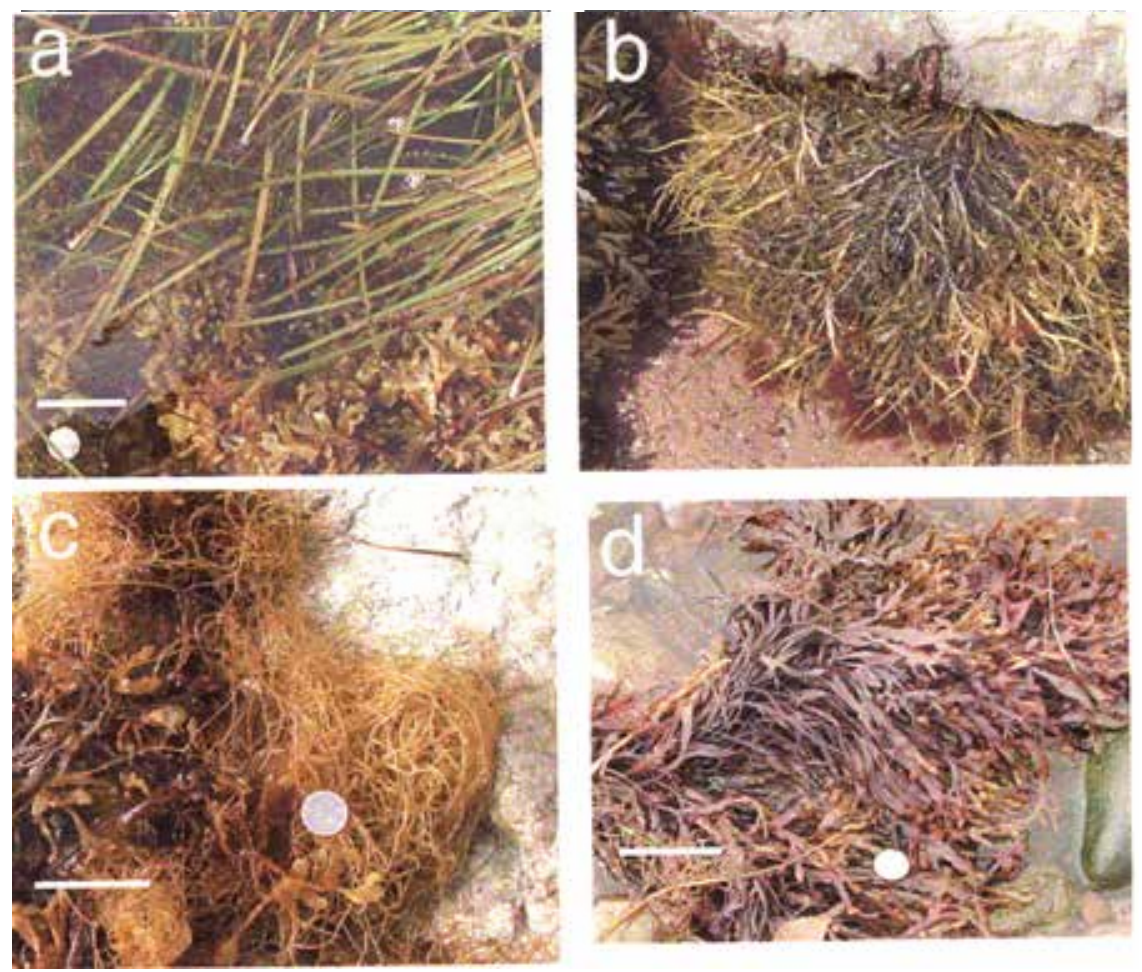

Fig 5 Photographs of eelgrass and some marine plants in Bras d'Or Lake taken in October 2001. (a) Zostera marina and Chondrus crispus near Eskasoni; (b) Rockweed Ascophyllum nodosum from near Barra Strait. Reddish tufts at the outer ends is a reddish epiphytic alga (Polysiphonia lanosa). Another rockweed, Fucus vesiculosus is to the left; (c) Gracilaria tivaidae (under coin) with some Fucus; (d) Fucus vesiculosus from Benacadie Point. White scale bar is $5 \mathrm{~cm}$.

form of shoreline vegetation was eelgrass (Zostera marina, a flowering angiosperm - Fig 5a). It was present throughout the Bras d'Or Lakes in silt and mud. Marine algae occupied a narrow band to a depth of 3-4 m. A total of 92 species of marine benthic algae were recorded and McLachlan and Edelstein (1971) recognized two algal associations. One association was characteristic of the open coast of Cape Breton Island, consisting primarily of rockweeds (Ascophyllum sp. and Fucus sp. - Fig 5b,d) with some kelp (Laminaria sp.) and Irish moss (Chondrus crispus - Fig 5a). This association was most developed in the Great Bras d'Or Channel, but was also found in St. Andrew's Channel, in West Bay and in the western portion of East Bay. The other algal association was characteristic of the warmer waters of shallow protected 
embayments, and commonly consisted of free-living forms of seaweeds such as Gracilaria (Fig 5c), Ascophyllum, and several other species. The warm-water association was found mainly in St. Patrick's Channel, Denys Basin and North Basin where eelgrass dominated. The upper reaches of East Bay and St. Peter's Inlet were also dominated by eelgrass, but the warm-water algae were poorly represented.

Biogeographic associations Because of the diversity of habitats within the Lakes, several biogeographic groups can be recognized within different taxa: Virginian, Boreal-Arctic and Arctic. The Virginian species (sometimes called warm-water or temperate) have their centres of distribution south of Cape Cod; Boreal-Arctic (cold water) species have their centres of distribution somewhere between Labrador and the Gulf of Maine, and Arctic species are found mainly in the Arctic but have isolated pockets of distribution to the south. These Arctic species are thought to be glacial relicts, left behind in localized colder areas when the ice sheets retreated northward.

The warm-water species association within the Bras d'Or Lakes is typified by the eastern oyster Crassostrea virginica. Oysters are near their northern limit in the Lakes and are restricted to the protected coves that warm substantially in summer. A warm-water component is also seen in the marine flora (McLachlan and Edelstein, 1971), selected nearshore invertebrates (Bousfield and Thomas, 1975), polychaetes (Fournier and Pocklington, 1984) and benthic foraminiferans (microscopic, single-celled organisms with outer shells, Vilks,1967). An Arctic component was also identified in each of the above studies, with the exception of the marine flora.

As part of a larger study of littoral marine invertebrates (mainly crustaceans and molluscs) in eastern Canada and New England, Bousfield and Laubitz (1972) had 3 collection stations in Bras d'Or Lakes. Samples were semi-quantitative with dip nets or by hand collection from shore in the St. Patrick's Channel-Denys Basin area. Based on these samples and knowledge of the seasonal temperature regime, Bousfield and Thomas (1975) grouped Bras d'Or Lakes with the southwestern Gulf of St. Lawrence. Within this region Virginian species live in close proximity with Boreal-Arctic species. A subarctic mysid (Mysis gaspensis; mysids are small, shrimp-like crustaceans) at the Nyanza station in the Bras d'Or Lakes was noted by Bousfield and Laubitz (1972) and they suggested that sharp seasonal and vertical thermoclines permit warm- and cold-water fauna to exist virtually side by side.

Benthic foraminiferans were sampled by an Ekman dredge or core sampler at 259 stations throughout the Bras d'Or Lakes by Vilks (1967). Depths ranged from 1-230 m. Many of the species were the same as those present further south (Mahone Bay NS, Portsmouth NH) but there was also an Arctic element. Eight groups of stations were identified based on the species composition. One group was in the outer reaches of the Great Bras d'Or Channel, while other groups were associated with particular habitats characterized by bottom type, current or depth.

Polychaetes were sampled in 1981 at 24 stations throughout the Lakes with an epibenthic sled, a Van Veen grab and a trawl (Fournier and Pocklington, 1984). Depths ranged from 9-195 m. More than 70 species were identified. These species were classified as Virginian, Boreal-Arctic, Arctic or Cosmopolitan. The Great Bras $d^{\prime}$ Or Channel was recognized as distinct based on its high percentage of Virginian species. The St. Patrick's Channel area had a similar percentage of Virginian species and perhaps would have shown a higher percentage if shallower depths had been sampled (i.e. oyster bottom). St. Andrew's Channel had the highest percentage of Boreal-Arctic and Arctic species, presumably because it is cold year-round at depth. 


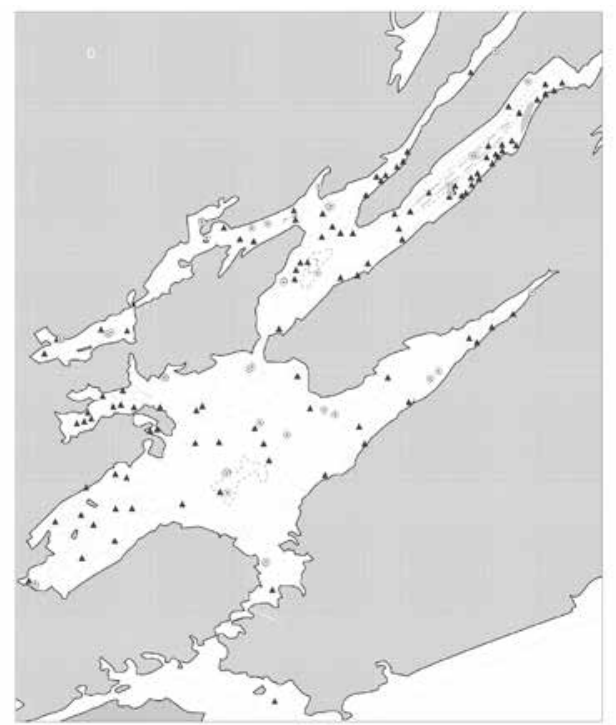

Fig 6 Locations of trawling stations in 1967 ( $\mathbf{\Delta}$, MacDonald 1968) and 1999-2000 (๑) Lambert).

\section{Epibenthic Invertebrate Distribution: Sources of Information}

Other than the above studies of polychaetes and foraminiferans, there have been no targeted studies of invertebrate distribution throughout the Bras d'Or Lakes. Trawls or drags have been used in several studies of the fish fauna and some epibenthic invertebrates were recorded along with the fish (Table I, Fig 6). Since trawls are limited to bottom depths of greater than 5-10 m, the shallow water epibenthos is under-represented in these data sets. In addition the tow lengths are several kilometres, so the distribution data from trawl surveys are coarse in scale. Resource assessment and fishery data are available for some commercial species such as lobsters and oysters.

Table I. Studies in the Bras d'Or Lakes that have documented the distribution of large epibenthic invertebrates. Stn $=$ station. $\mathrm{nm}=$ nautical mile. $=1.855 \mathrm{~km}$

\begin{tabular}{|c|c|c|c|c|c|}
\hline Dates & Objective & Methods & $\begin{array}{l}\text { Benthic invertebrate } \\
\text { speciesgroups } \\
\text { recorded }\end{array}$ & Locations & Reference \\
\hline
\end{tabular}

May 1951- Aspects

Aug. 1952 of the biology of codworm (now known as sealworm)

Sept-Oct. Fish population Trawl (3/4 1967

Yankee 35),

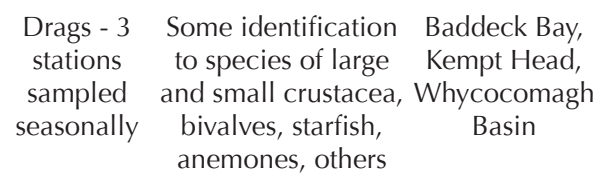

Black 1976
Lobsters, crabs scallops

Throughout MacDonald 1968

$115 \mathrm{stn}$, tow for

25-120 min

(average $3 \mathrm{~nm}$ ) 
Table I (cont'd)

\begin{tabular}{|c|c|c|c|c|c|}
\hline $\begin{array}{l}\text { May 1999, } \\
2000\end{array}$ & $\begin{array}{l}\text { Survey of fish } \\
\text { distribution, } \\
\text { focus on cod }\end{array}$ & $\begin{array}{l}\text { Flounder trawl } \\
21 \text { stn in } 1999 ; \\
18 \text { in } 2000, \\
\text { tow length } 1 \mathrm{~nm}\end{array}$ & $\begin{array}{l}\text { Lobsters, crabs, } \\
\text { mussels, scallops } \\
\text { starfish, urchins }\end{array}$ & Throughout & $\begin{array}{c}\text { Lambert } \\
\text { (unpublished) }\end{array}$ \\
\hline $\begin{array}{l}\text { Summer } \\
1999,200\end{array}$ & $\begin{array}{l}\text { Survey of green } \\
\text { crab distribution }\end{array}$ & $\begin{array}{l}\text { Cylindrical } \\
\text { wire traps }\end{array}$ & Crabs & Throughout & $\begin{array}{c}\text { Paul } \\
\text { (unpublished) }\end{array}$ \\
\hline $\begin{array}{l}\text { Oct. } 2001 \\
\text { distribution }\end{array}$ & Survey of lobster & $\begin{array}{c}\text { Wire lobster } \\
\text { traps }\end{array}$ & Lobsters, crabs & $\begin{array}{c}\text { Cape Dauphin } \\
\text { to North Basin; } \\
\text { East Bay }\end{array}$ & $\begin{array}{c}\text { Tremblay } \\
\text {; (unpublished) }\end{array}$ \\
\hline
\end{tabular}

Traditional knowledge of the Bras d'Or Lakes biota comes from both the Mi'kmaq and non-native communities that surround the Lakes and maps of distribution for some species have been completed (Eskasoni Fish and Wildlife Commission and Dept. of Fisheries and Oceans, 1996). Finally there have been several biological studies within the Lakes that are area- and or group- specific. These include recent trapping studies to document the distribution and relative abundance of green crab and lobster. Some of the results of these latter trapping studies are provided here.

The above sources have been used to compile a list of the known invertebrate fauna within the Bras $d^{\prime}$ Or Lakes ${ }^{1}$. While the list is probably fairly complete for the shallow water fauna, the deeper areas of the Lakes are less studied and probably contain undocumented species. The list for decapod crustaceans (species with five pairs of appendages attached to the thorax), mollusca and echinoderms is presented in Table II. Unless otherwise stated, the common names used in this paper correspond to the scientific names in Table II.

Table II List of large epibenthic animals found in the Bras d'Or Lakes. Included are Decapoda, Mollusca and Echinodermata. For source, see text footnote 1.

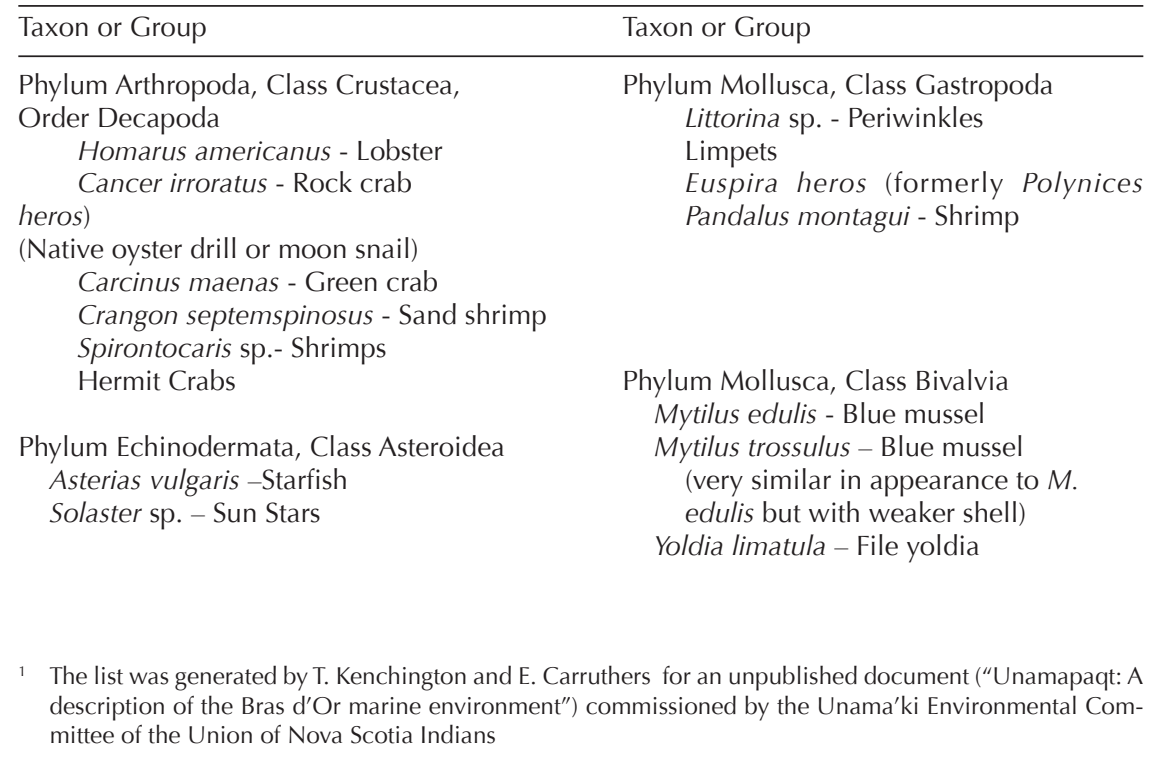


Table II (cont'd) Phylum Echinodermata - Class Ophiuroidea
Brittle stars

Phylum Echinodermata - Class Echinoidea Strongylocentrotus droebachiensis - Sea urchin

Phylum Echinodermata - Class Holothuroidea Sea cucumbers
Phylum Mollusca, Class Bivalvia (cont'd)

Hiatella arctica - Arctic rock borer

Crassostrea virginica -

Eastern or American oyster

Mercenaria mercenaria - Quahog

Ensis directus - Atlantic razor clam

Mya arenaria - Softshell clam

Spisula solidissima - Bar clam

Placopecten magellanicus - Sea scallop

Anodonta sp. - Freshwater mussel

\section{Life Histories of Epibenthic Invertebrates}

Benthic invertebrates have a diversity of life histories. Eggs are fertilized externally (e.g. bivalves) or prior to release (e.g. crustaceans). Most epibenthic invertebrates have a planktonic larval stage, but upon settling, different species adopt a sedentary (e.g. bivalves) to mobile (e.g. lobsters) existence. Growth is continuous in most groups but is discontinuous in crustaceans which shed their outer shell during the molting process. Life spans can be one to many years. Feeding can be by filtration (e.g. bivalves), grazing (e.g. sea urchins) or by active predation (e.g. lobsters, crabs).

Benthic invertebrate females are typically highly fecund. A one pound female lobster can produce 10,000 eggs in one clutch and many more in her lifetime. Adult oysters and sea urchins can produce millions of eggs per year. The size of the larvae at hatching is related to the number produced: lobster larvae are 5-10 mm in length while oyster larvae are less than one thirtieth this size. In some groups (e.g. bivalves, sea urchins), fertilization is external, with eggs and sperm released to the water during spawning. In these groups it is critical that mates be nearby or fertilization will fail. In other groups (e.g. lobsters, crabs), fertilization is internal, or at least takes place while eggs and sperm are attached to the animal. Overall fertilization success is higher with internal fertilization, and species that use this method typically have lower fecundity than species with external fertilization.

The lobster Homarus americanus passes through 3 larval stages and a postlarval stage. Only the postlarva, with its well-developed antennae and claws, is readily recognizable as a young lobster. Larval stages 1-3 are strictly planktonic (floating with the currents), while the post-larva begins to spend more time near the bottom, and has good swimming ability. Crab larvae pass through several zoeal stages (marked by long anterior and dorsal spines) and a megalopa stage (relatively crab-like, this is the stage prior to metamorphosis to the adult form). Bivalve larvae are sometimes called veliger larvae, characterized by a thin shell and a velum. The velum is a two lobed organ with fine hair-like cilia that is used for locomotion and feeding. Sea urchin eggs are fertilized externally and develop into echinopluteus larvae, which are characterized by 4 pairs of elongated arms used for swimming and feeding.

The survival of the larvae of marine benthic invertebrates is very low $(<<1 \%)$ but since many larvae are produced, only a small fraction needs to survive to maintain the population. Small differences in the survival rate can make large differences in the numbers of young juveniles in any given year. The range over which a given group of larvae is dispersed will depend upon the water currents and the duration of the planktonic period. Currents vary with time of year and local wind events; the duration of the planktonic period depends on temperature and possibly food. 
Metamorphosis is an abrupt transformation from one life history stage to another. In the case of epibenthic invertebrates, settlement to the bottom is usually associated with metamorphosis from the larval to juvenile form. Some species, such as lobsters are highly selective in where they settle, preferring cobble bottoms. Other species, such as rock crab, discriminate less (Palma et al., 1999). As newly settled juveniles, epibenthic invertebrates are attractive food items and can be subject to high predation rates. Lobsters and crabs can adopt cryptic and evasive behavior, but this is not an option for sedentary species such as oysters. As they grow, epibenthic invertebrates generally become less susceptible to predation. Some species, such as lobsters and crabs become much more mobile and can undertake seasonal migrations.

The processes of larval delivery, settlement and post-settlement survival of invertebrate larvae are fundamental to the dynamics of marine invertebrate populations, and to the overall species composition of invertebrates in a given area. Research on how multiple ecological factors operate at each phase of the life cycle are needed to understand how marine communities are structured (Morgan, 2000).

\section{Tolerances to Low Salinity}

One of the key physical features of the Bras d'Or Lakes is the lower salinity compared to the open ocean (Fig 3). In other estuaries the species richness (number of species present) declines from the open ocean to a minimum at a critical salinity (usually 5-8). This trend reflects the inabilities of many species to tolerate salinity stress and to undergo extensive cell volume regulation. Further up the estuary, as salinity decreases, freshwater species begin to occur and species richness increases (Kennish, 1990). Studies on the tolerance of epibenthic invertebrates to low salinity (Table III)

Table III Laboratory studies or field observations of salinity tolerance of some epibenthic invertebrates found in Bras d'Or Lakes. None of the animals in these studies originated in Bras d'Or Lakes. $\mathrm{d}=$ day; $\mathrm{Z} 4$ = zoea stage 4.

\begin{tabular}{|c|c|c|c|c|}
\hline Species & Stage & Tolerance indicator $(\mathrm{s})$ & Salinity & Reference \\
\hline Lobster & Larvae 1-3 & $50 \%$ mortality $\left(2 \mathrm{~d}, 20^{\circ} \mathrm{C}\right)$ & $14-17$ & Charmantier et al., 19 \\
\hline Post larvae & \multicolumn{2}{|c|}{$50 \%$ mortality $\left(3 \mathrm{~d}, 20^{\circ} \mathrm{C}\right)$} & $12-13$ & Charmantier et al., 19 \\
\hline Adults & \multicolumn{2}{|c|}{$50 \%$ mortality $\left(2 \mathrm{~d}, 15^{\circ} \mathrm{C}\right)$} & $8.2-11$ & McLeese, 1956 \\
\hline \multirow[t]{2}{*}{ Rock Crab } & Zoea 1-4 & $50 \%$ mortality $\left(4 \mathrm{~d}, 15^{\circ} \mathrm{C}\right)$ & $14-21$ & Charmantier and \\
\hline & \multicolumn{2}{|c|}{ Z4-Megalopa $50 \%$ mortality $\left(4 \mathrm{~d}, 15^{\circ} \mathrm{C}\right)$} & $17-28$ & Charmantier-Daures, \\
\hline Adults & \multicolumn{2}{|c|}{$50 \%$ mortality $\left(2 \mathrm{~d}, 15^{\circ} \mathrm{C}\right)$} & 8.5 & 1991 \\
\hline \multirow{3}{*}{ Green Crab } & \multirow{2}{*}{ Larvae } & $100 \%$ mortality $\left(9 \mathrm{~d}, 17^{\circ} \mathrm{C}\right)$ & 15 & Anger et al., 1998 \\
\hline & & $\begin{array}{l}\text { Reduced survival and growth } \\
\text { compared to } 25\left(>50 \mathrm{~d}, 17^{\circ} \mathrm{C}\right)\end{array}$ & 20 & Anger et al., 1998 \\
\hline & Adults & $\begin{array}{l}\text { Survival over extended periods } \\
\text { in nature }\end{array}$ & 6 & Anger et al., 1998 \\
\hline \multirow[t]{2}{*}{ Sea Scallop } & Adults & $50 \%$ mortality $\left(3 \mathrm{~d}, 1^{\circ} \mathrm{C}\right)$ & 11.5 & Bergman et al., 1996 \\
\hline & \multicolumn{2}{|c|}{$50 \%$ mortality $\left(10 \mathrm{~d}, 1{ }^{\circ} \mathrm{C}\right)$} & 17 & \\
\hline Blue Mussels & Adults & $97 \%$ survival $\left(6 \mathrm{~d}, 10^{\circ} \mathrm{C}\right)$ & 5 & Bailey et al., 1996 \\
\hline Horse Mussels & Adults & $\begin{array}{l}\text { At least } 50 \% \text { mortality } \\
\left(21 \mathrm{~d}, 21^{\circ} \mathrm{C}\right)\end{array}$ & 22 & Pierce, 1970 \\
\hline
\end{tabular}


Table III (cont'd)

\begin{tabular}{|c|c|c|c|c|}
\hline Oysters & $\begin{array}{l}\text { Adults } \\
\text { Adults }\end{array}$ & $\begin{array}{l}100 \% \text { mortality }\left(5 \mathrm{~d}, 25^{\circ} \mathrm{C}\right) \\
\text { Reduced growth }\end{array}$ & $\begin{array}{l}7 \\
<14\end{array}$ & $\begin{array}{l}\text { Wells, } 1961 \\
\text { Shumway, } 1996\end{array}$ \\
\hline Sea urchins & $\begin{array}{l}\text { Larvae } \\
50 \% \mathrm{~m} \\
\text { Adults }\end{array}$ & $\begin{array}{l}50 \% \text { mortality }\left(3 \mathrm{~d}, 10^{\circ} \mathrm{C}\right) \\
\text { y }\left(10 \mathrm{~d}, 10^{\circ} \mathrm{C}\right) \\
50 \% \text { mortality }\left(3 \mathrm{~d}, 10^{\circ} \mathrm{C}\right) \\
50 \% \text { mortality }\left(10 \mathrm{~d}, 10^{\circ} \mathrm{C}\right)\end{array}$ & $\begin{array}{l}23 \\
25 \\
11 \\
11\end{array}$ & $\begin{array}{l}\text { Roller and Stickle, } 1994 \\
\text { " } \\
\text { " }\end{array}$ \\
\hline
\end{tabular}

can be used as a guide to how sensitive these species might be to the reduced salinities within the Bras d'Or Lakes. The tolerances in Table III are not necessarily definitive for Bras d'Or Lakes' animals, since some species may have adapted to the conditions of the Lakes. This appears to be the case for cod in the Lakes which are more tolerant of reduced salinities than cod from outside the Lakes (Lambert, 2002). Here it is hypothesized that the relative salinity tolerances of different species in the Lakes are the same as have been measured elsewhere.

For species where both adults and larvae have been studied, it is clear that the larval stages are most sensitive. For example, a study of adult lobsters indicates that $50 \%$ can survive salinities as low as 8 , but $50 \%$ of stage 1-3 larvae will survive only at salinities of 14-17. Mortalities are only a coarse measure of the effects of low salinity and sublethal and behavioral effects will occur long before animals die. Adult lobsters suffer physiological stress at salinities of 15 and below (Jury et al., 1994). More examples are discussed below.

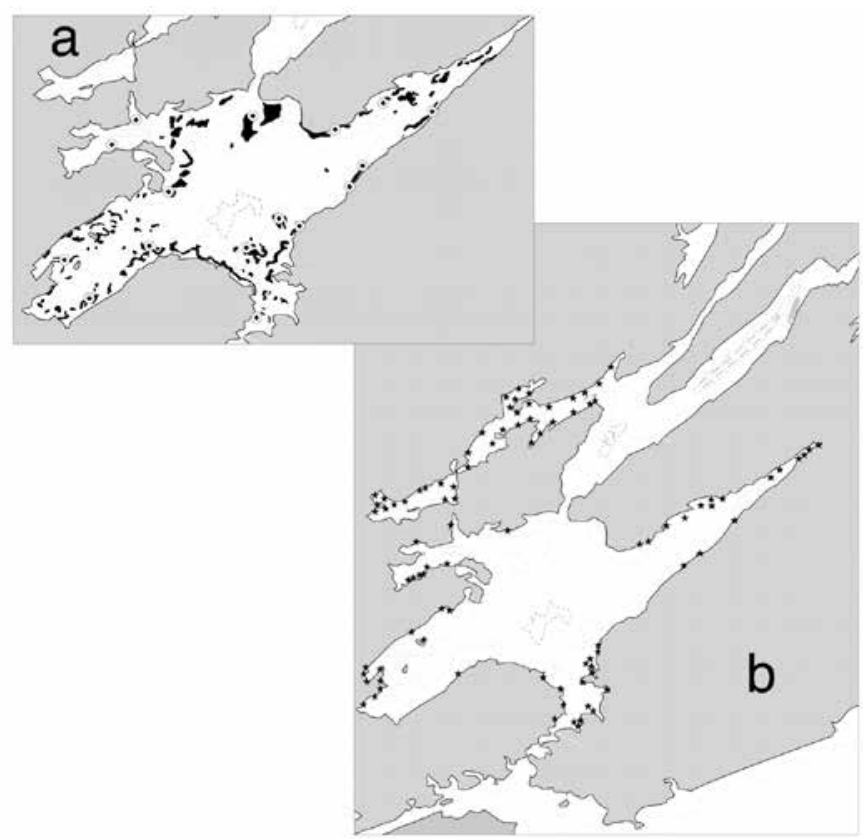

Fig 7 Maps of (a) lobsters (areas in black) and rock crabs (@); (b) oysters (Eskasoni Fish and Wildlife Commission and Dept. Fisheries and Oceans, 1996) 


\section{Distribution, Harvest and Possible Limiting Factors of Some Key Species}

The following discussion covers a number of species, but lobsters (Homarus americanus) and oysters are the two species with the most information. They are representative of two groups with widely different life histories (decapod crustaceans and bivalve molluscs). They serve to illustrate that the distribution and production of epibenthic invertebrates may be determined by multiple factors.

Lobsters The map based on traditional knowledge shows areas where lobsters and rock crabs are found within Bras d'Or Lake (Fig 7). Mapping traditional knowledge is ongoing and will include all of Bras d'Or Lakes when complete. Both lobsters and crabs are found primarily at depths less than 20-30 m, often in the same vicinity. The locations of lobster bottom are more or less coincident with lobster fishing effort based on a survey of the distribution of lobster trap buoys during the 1993 fishery (Stevens, 1993).

Each of the trawl surveys for fish fauna has mentioned lobsters. Black (1976) reported that lobsters were one of the characteristic invertebrates found within Baddeck Bay. The 1967 survey (MacDonald, 1968) reported a total of 47 lobsters in the 115 trawl sets. The highest catch per tow was in the Great Bras d'Or Channel (Fig 8). The overall catch rate in Bras d'Or Lake was 0.6 per tow. In the 39 trawls conducted in 1999-2000, only two lobsters were captured, one in East Bay and one in the North Basin (Fig 9). A decline in lobster abundance between 1967 and the late 1990s is consistent with anecdotal information (see below) but the surveys are not directly comparable because of differences in gear and tow length (Table I), and station distribution (Table IV).

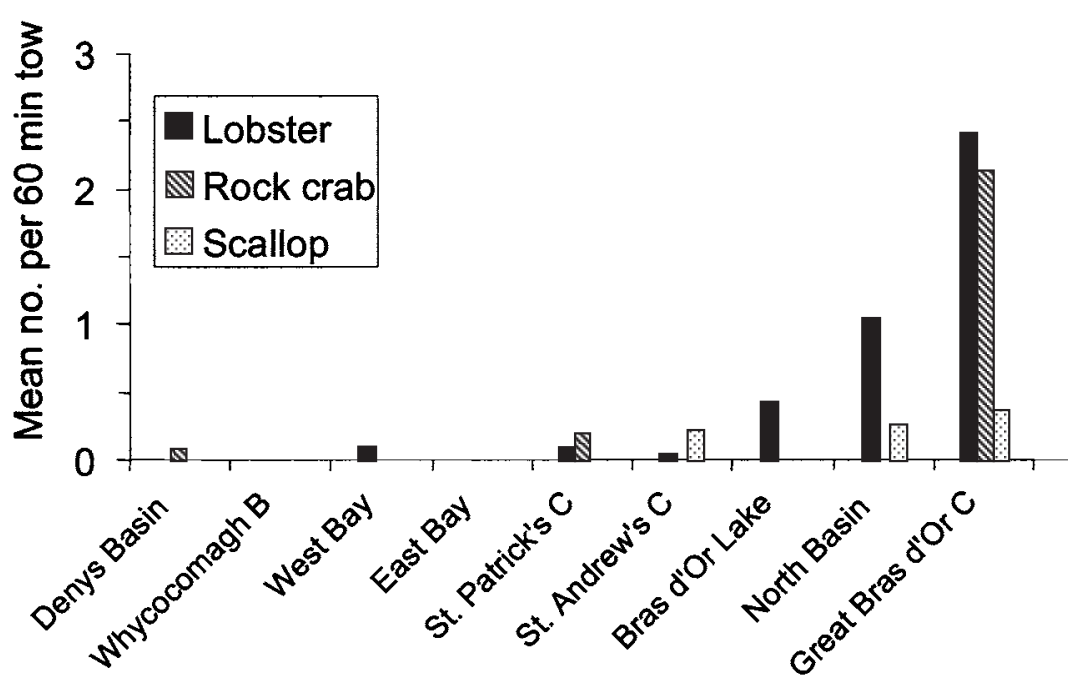

Fig 8 Mean number per standard tow of selected epibenthic invertebrates in 1967. (MacDonald 1968; Table IV) The data are standardized to a 60 min tow duration. One tow in St. Peter's inlet is not included. 

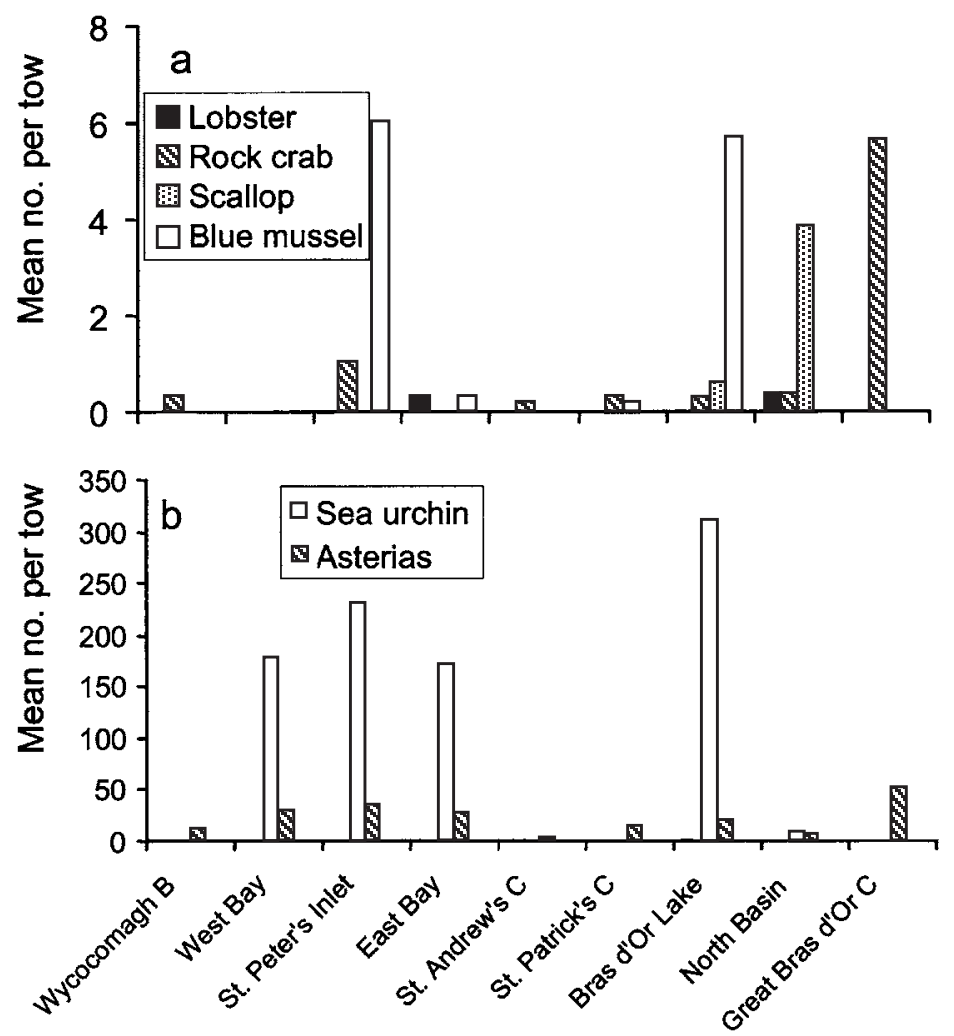

Fig 9 Mean number per standard tow of selected epibenthic invertebrates in 19992000 (Lambert 2001, Table IV). The data are standardized to a tow length of 1 nautical mile (= approximately $1.8 \mathrm{~km})$.

Table IV Distribution of trawl survey stations in 1967 and 1999-2000.

\begin{tabular}{lcccccc}
\hline Stations & $\begin{array}{c}\text { No. } \\
\text { mean } \\
(\mathrm{m})\end{array}$ & $\begin{array}{c}\text { Depth } \\
\text { range } \\
(\mathrm{m})\end{array}$ & $\begin{array}{c}\text { Depth } \\
\text { stations }\end{array}$ & $\begin{array}{c}\text { No. } \\
\text { mean } \\
(\mathrm{m})\end{array}$ & $\begin{array}{c}\text { 1999-2000 } \\
\text { Depth } \\
\text { range } \\
(\mathrm{m})\end{array}$ & Depth \\
\hline Denys Basin & 10 & 9 & $6-15$ & 0 & & \\
Little Narrows to Wycocomagh & 4 & 10 & $6-28$ & 4 & 18 & $7-29$ \\
West Bay & 11 & 35 & $17-55$ & 2 & 16 & $15-17$ \\
East Bay & 6 & 51 & $26-65$ & 3 & 20 & 20 \\
Johnstown Harbour to St. Peter's Inlet & 1 & 17 & 17 & 2 & 20 & 20 \\
St. Andrew's Channel & 34 & 49 & $22-92$ & 5 & 169 & $27-263$ \\
St. Patrick's Channel & 6 & 17 & $15-20$ & 6 & 12 & $8-18$ \\
Bras d'Or Lake & 18 & 33 & $18-107$ & 11 & 66 & $12-134$ \\
North Basin & 17 & 30 & $18-55$ & 3 & 34 & $26-40$ \\
Great Bras d'Or Channel & 8 & 26 & $18-107$ & 3 & 17 & $10-22$ \\
TOTAL NO. & 115 & & & 39 & & \\
\hline
\end{tabular}


Lobster catch rates during recent (October 2001) trapping surveys can be used to indicate relative lobster abundance (Fig 10). A total of 240 trap hauls were made from Cape Dauphin to North Basin with wire traps from a commercial lobster boat using mackerel as bait. Inside Bras d'Or Lake similar traps were employed with herring used as bait; data from 71 trap hauls are presented. Outside Bras d'Or Lake, average catch rates (number of lobsters per trap haul averaged over at least 10 traps) diminished from over 5 off Cape Dauphin and in the outer Great Bras d'Or, to less than 1 by Red Head (Fig 10). Catch rates were 1-2 on the western side of the North Basin. Within Bras d'Or Lake average catch rates were much lower, never exceeding 0.6 per trap haul. While some of this difference may be related to bait, the low catch rates within Bras d'Or Lake are consistent with the trawl data, and what is known from the commercial fishery (see below).

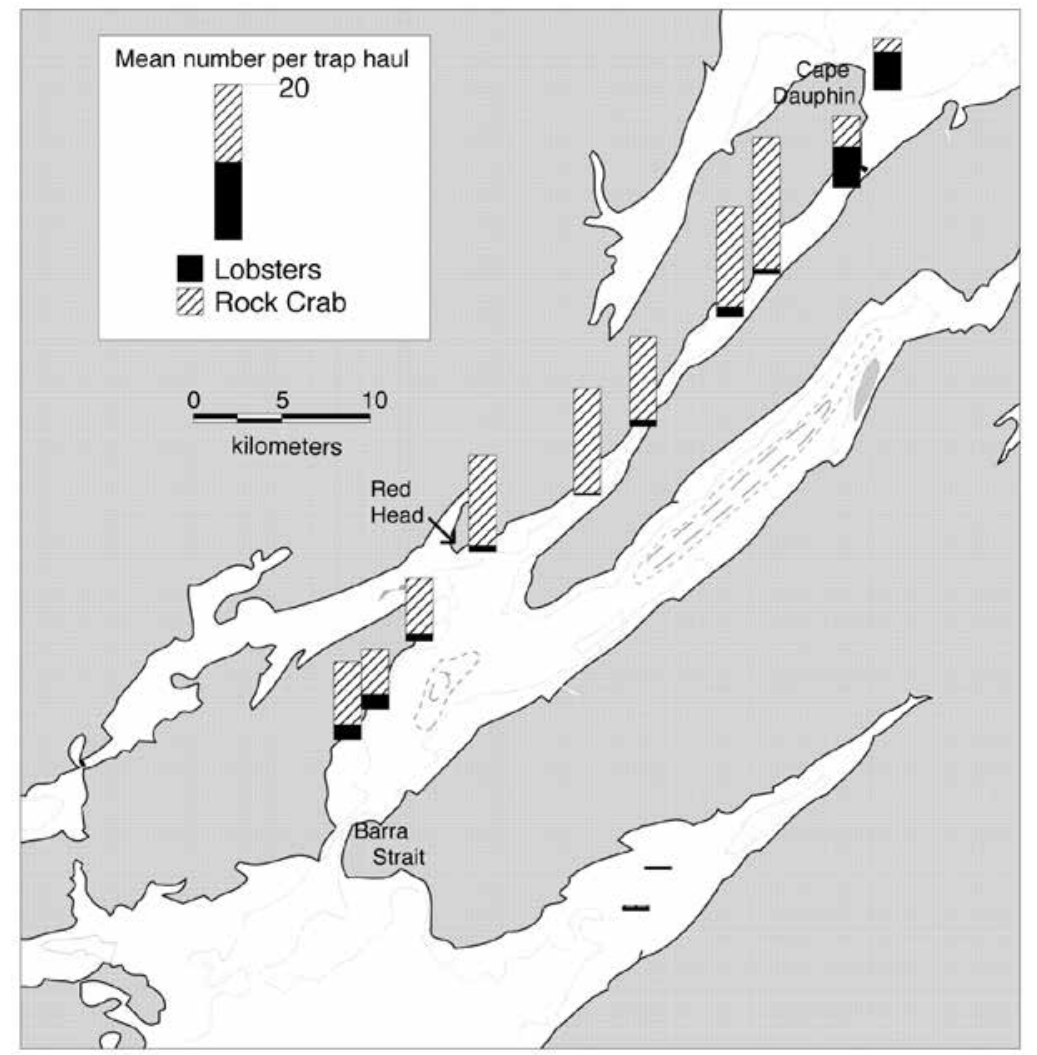

Fig 10 Mean catch per trap haul of lobsters and crabs from Cape Dauphin to Barra Strait and within Bras d'Or Lake. Data were obtained by fishing wire lobster traps from Oct. 8-12, 2001 (outside Bras d'Or Lake) and Oct. 3-5, 2001 (inside Bras d'Or Lake). 
Mi'kmaq elders indicate lobsters in Bras d'Or Lake were more abundant 30 or more years ago; others who have worked in the Lakes for many years have recollections of higher lobster catches in the 1960s (Lambert, 2001). Unfortunately the apparent decline in catches cannot be reliably quantified. Prior to 1988 separate landings data for Bras d'Or Lake were not maintained by the Department of Fisheries and Oceans. Currently the lobster fishery in Bras d'Or Lake is small, with only 5 metric tons of reported landings in the year 2000. The fishery in the Great Bras d'Or Channel and North Basin is more productive, but because no fishermen set traps exclusively in this area, the fishery catch for the Great Bras d'Or Channel cannot be separated from the data for Sydney Bight.

The extent of exchange between the lobsters in the Lakes and the open coast of Cape Breton is not known. Exchange could occur at the larval or bottom-dwelling stages. A unique aspect of the lobsters in the Bras d'Or Lakes is the occurrence of a bright orange colourmorph (Fig 1a). Lobsters occur in a number of colours other than the familiar greenish-brown, including orange, blue, white, and various combinations. These colourmorphs are generally rare in lobster populations, but the orange version appears to occur in higher frequency in the Bras d'Or Lakes than outside the Lakes. Since the orange colourmorph is genetically based, it suggests the Bras d'Or Lakes lobsters may be genetically isolated to some extent. Whether such genetic isolation exists will be determined from an ongoing study of the genetics of lobsters from widely different locations in the Maritimes, including lobsters from the Bras d'Or Lakes (Jones, 2001). Whether adult lobsters move between the Lakes and the outer coast could be studied by tagging lobsters and monitoring their movement. Larval exchange would be better understood by studying the distribution of planktonic larvae in combination with the development of realistic models of the physical circulation.
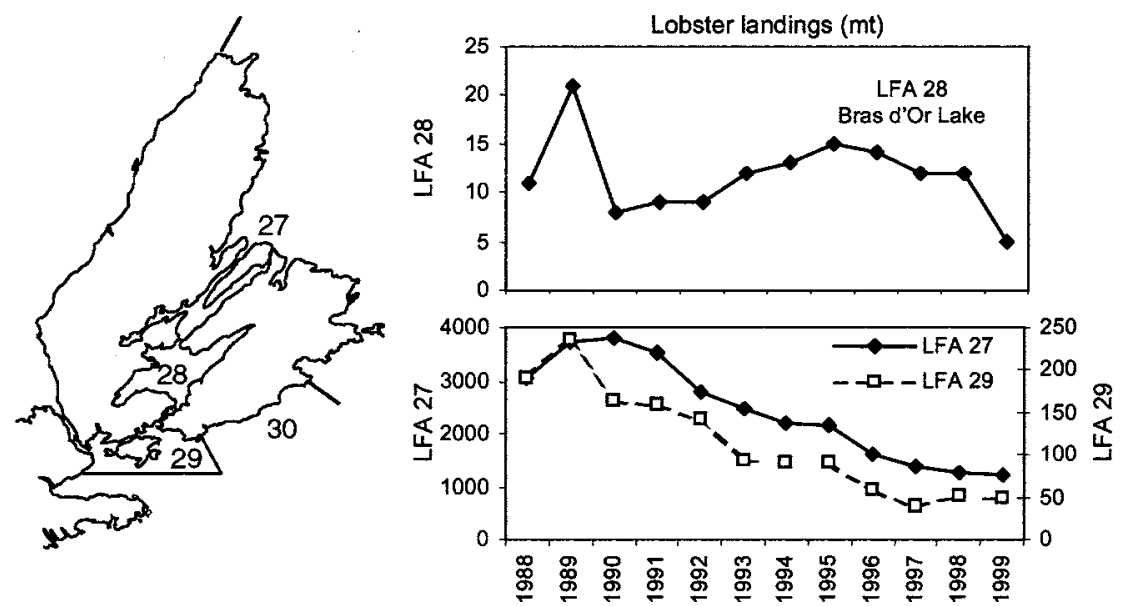

Fig 11 Map of Lobster Fishing Areas (LFAs) and lobster landings in metric tons since 1988 for LFA 28 (Bras d'Or Lake), LFA 27 and LFA 29. 
Bras d'Or Lake comprises Lobster Fishing Area (LFA) 28 and reported landings since 1988 have ranged from 5-21 tons (Fig 11). Unreported catches (legal and illegal) cannot be quantified. Illegal traps have been set for many years in the Lakes (anecdotal information from native and non-native fishermen) and there is no measure of whether this fishing activity has increased or decreased over the years. Nevertheless it is doubtful that this illegal trapping approaches the scale of the licensed fishery during the 1990s. A survey of lobster buoys in Bras d'Or Lake during the 1993 spring fishery estimated a minimum of 1820 buoys (each corresponding to a lobster trap) around the perimeter of the Lake (Stevens, 1993). Most effort (68\% of the buoys) was in West Bay and the mouth of St. Peter's Inlet. Fishing in the 1980s and 1990s was mainly by approximately 18 licensed commercial fishermen (license activity has fluctuated), with the First Nations fishery relatively small. By the end of 2001, all but 5 of these licenses had been purchased by Eskasoni First Nation.

Lobster landings within Bras d'Or Lake are low relative to Sydney Bight but both LFAs 27 and 28 experienced high landings in the late 1980s. Indeed the landings in LFA 27 were the highest recorded since 1874. Landings in LFA 29 (Atlantic side of St. Peter's Inlet) were also relatively high in 1989 but were far below the peak in the 1890s (Tremblay and Eagles, 1998). Similarities between Bras d'Or Lake and LFA 27 appear to have diminished since the early 1990s (Fig 11).

Scaling landings by area accentuates the differences in lobster production. Landings just north of St. Ann's Bay are coarsely estimated at 5-11 tons per km of coastline, compared with less than 0.1 tons per km of coastline in Bras d'Or Lake. Trap catch rates reflect this difference. In Bras d'Or Lake, the average catch rate of legal sized lobsters in June 2000 was 1.4 per 10 trap hauls (based on 356 trap hauls); just north of St. Ann's Bay the average catch rate during the spring 2000 fishery was 10.7 per 10 trap hauls (based on 3486 trap hauls).

Why are lobsters not more abundant in the Bras d'Or Lakes? Possible explanations are (i) marginal salinities (Fig 3); (ii) limited rocky bottom habitat (Fig 4); (iii) low food availability or (iv) insufficient egg production. The first 3 possible explanations are linked to inherent environmental limitations; the last could be the result of overfishing of lobsters in the Lakes.

Salinity in some parts of the Bras d'Or Lakes system is probably a limiting factor for certain stages of lobster. Tolerance of low salinities is lowest during the larval stages. Survival from egg to post-larva is about 25\% lower at salinities of 21-22 than at salinities of 31-32, and at salinities below 20, larval survival is greatly reduced (Ennis, 1995). Reduced larval survival might then be expected in areas where salinities approach 20, such as the near surface layer of Wycocomagh and Denys Basin, Nyanza Bay and possibly East Bay.

Lobster larvae have relatively good swimming ability and are known to migrate vertically (Harding et al., 1987). Although lobster larvae are most sensitive to low salinity after metamorphosis to the postlarval stage (when lobsters are about $1 \mathrm{~cm}$ long), in other areas (Northumberland Strait and Browns Bank) postlarvae are found predominantly near the surface (Scarratt, 1973; Harding et al., 1987). Whether postlarvae in the Bras d'Or Lakes avoid the low salinities of the near surface layers would require field studies of postlarvae vertical distribution.

Sublethal effects on larvae may occur at higher salinities (e.g. 20-25) but this has not been investigated. Even adult lobsters might be stressed by the lower salinities within the Bras d'Or Lakes. In other estuaries, adults 75-92 mm in carapace (body excluding the flexible tail) show few signs of stress when salinities are dropped from 30 to 20 (Jury et al., 1994), but at salinities of 10-15, oxygen consumption and heart rate both 
increase. This stress might be reflected in lower growth or reduced reproductive outputs. Reduced salinities might also result in adaptive seasonal movements. In coastal New Hampshire, lobsters avoid the low salinities of the upper estuary during spring but migrate up the estuary with the advance of summer (Watson et al., 1999). The warmer summer temperatures may benefit lobster growth and reproduction.

Habitat in Bras d'Or Lake may also be limiting to lobsters, particularly to the juvenile stages which prefer cobble type habitat to avoid predation. In a study of the distribution of newly settled lobsters in a New England estuary, no individuals were found on featureless, sedimentary bottoms, but young lobsters were present on cobble substrates (Wahle, 1993). Within Bras d'Or Lake, Vilks (1967) reported that of 197 stations sampled with an Ekman grab, just 11 were classified as mainly boulder. Given that in Vilk's (1967) classification boulders included grain sizes down to $16 \mathrm{~mm}$, it seems that areas with cobbles greater than about $10 \mathrm{~cm}$ are uncommon. More work is needed to quantify the type and areal distribution of cobble habitat within the Bras d'Or Lakes. New tools such as multibeam bathymetry, which has been carried out in some parts of the Lakes, should be very useful in this regard.

Insufficient food may result in lower survival or growth of lobsters in Bras d'Or Lake. For the Lakes as a whole, nutrient input is relatively low, resulting in a low level of primary production (Strain and Yates, 2002). Lobsters may be food-limited if this low primary production translates into low food for lobster larvae, or benthic food for juveniles and adults. Together with studies of food availability, studies of lobster condition inside the Lakes compared to Sydney Bight could help resolve whether food is limiting. Food availability might be a general factor limiting the production of epibenthic invertebrates in the Bras d'Or Lakes. The mean biomass per tow in the 1999-2000 trawl surveys was 13-30 times greater in Sydney Bight than in Bras d'Or Lakes (Lambert, 2001).

Another potentially important limiting factor for lobsters in the Bras d'Or Lakes is insufficient egg production. Although the proportion of ovigerous females in the Lakes is fairly high compared to the outer coast there may be just too few reproductive female lobsters to produce enough eggs to develop into a large number of young juvenile lobsters. Using catch rates as an index of abundance, there are a lot fewer reproductive females per km of coastline in the Bras d'Or Lakes than in Sydney Bight. If we accept that lobster production in the past was higher, then this indicates the habitat can support more lobsters than at present. The current low egg production may have resulted from excessive removals in the past (both legal and illegal). Given that the Bras d'Or Lakes provide less than ideal conditions for lobsters, the lobster population that does exist there may be more sensitive to fishing pressure.

Low salinity, and possibly limited habitat, food, and low egg production may interact to limit the current production of lobsters within the Bras d'Or Lakes. The relative effects of habitat availability, physiological stress and larval supply on the distribution of lobsters along estuarine gradients are complex even when good data on lobster distribution are available (Wahle, 1993). Whether the lobster population within the Bras d'Or Lakes can be enhanced requires an understanding of which factors are most important. For example if larval survival is low because of reduced salinity, then enhancement by supplementing the population with hatchery reared juveniles may be possible. If on the other hand egg production were limiting, then the best approach would be to add reproductive sized lobsters to the Lakes from adjacent areas. If habitat is limiting at the juvenile stage, then the construction of artificial reefs should increase lobster production. 
Rock crab In both the 1967 and in the more recent trawl surveys the highest catch rates of rock crab (Cancer irroratus) were in the Great Bras d'Or Channel (Fig 8,9). The recent trapping survey for lobsters found that rock crab catch rates were highest in the middle and upper part of the Great Bras d'Or Channel, and lowest in Bras d'Or Lake. Commercial rock crab fishing occurs mainly on the ocean side of Seal Island, with catch rates comparable to Sydney Bight (5-10 kg per trap haul), but directed fishing has also occurred on an exploratory basis in the North Basin and in St. Patrick's Channel. The reduced salinities of the Lakes probably influences rock crab production more than lobsters. Adults are typically found in waters of 25-35 (Bigford, 1979) but are similar to lobsters in their tolerance of reduced salinity, with half surviving at 8.5 (Table III). The larval stages are much less tolerant. At $15^{\circ} \mathrm{C}$ half of zoea larvae die in 4 days at salinities of 13-17. In the megalopa stage salinity tolerance is at a minimum, with a $50 \%$ mortality at a salinity of 28 after 4 days. If the rock crab in the Bras d'Or Lakes have not adapted to lower salinities, many will be unable to achieve metamorphosis in much of the Bras d'Or Lakes.

Green crab Green crab (Carcinus maenas) are a recent arrival to the Bras d'Or Lakes. They were reported to be absent from Cape Breton by Pohle (1990) but were noted in Port Hawkesbury (just outside Bras d'Or Lakes) in 1992 by a lobster fisherman (Langeley, 2000). They likely entered the Lakes sometime between 1992 and 1995. Most common in protected embayments, green crab are voracious predators of bivalves such as clams and mussels (Elner, 1981). Because of the potential effect of

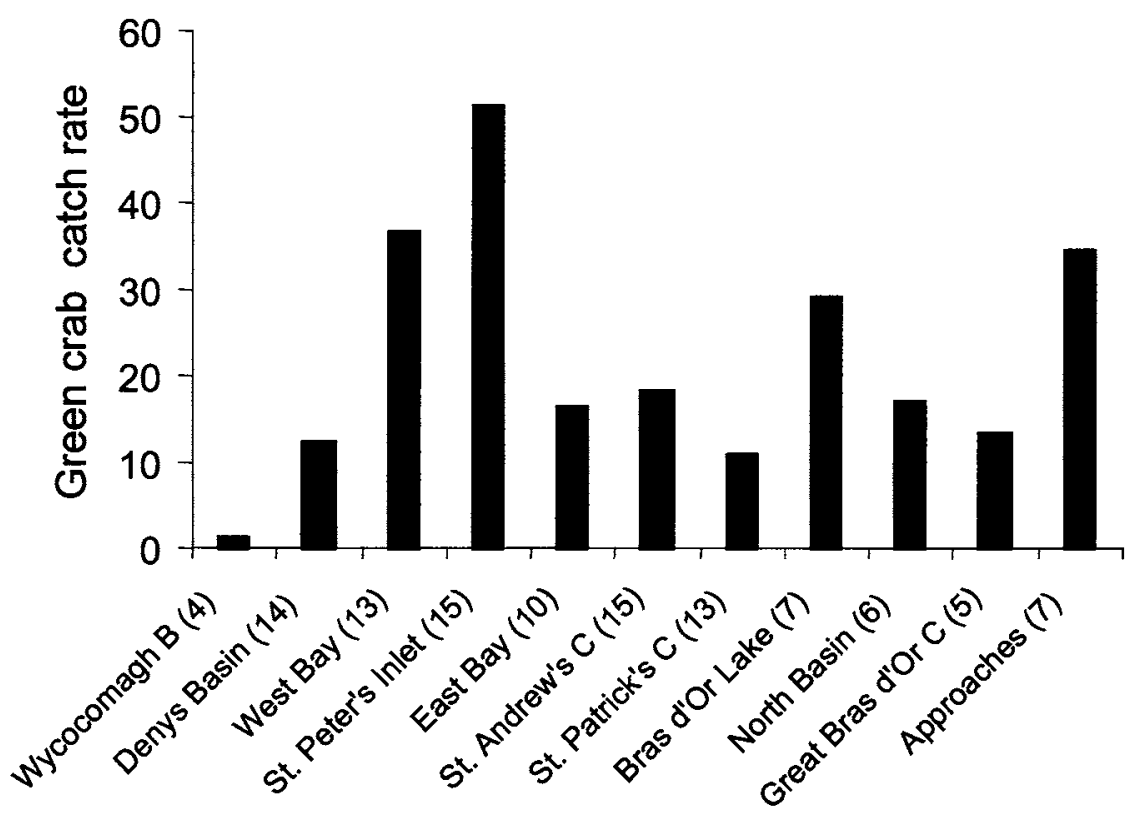

Fig 12 Green crab catch rates (no. per 3 traps set for 3-5 hr) in different areas of the Bras d'Or Lakes. The number of stations per area is in brackets. "Approaches" is between Carey Pt. and Cape Dauphin (Fig 2). 
green crabs on oysters, the Unama'ki Institute of Natural Resources (UINR) initiated a study of green crab distribution and biology in 1999. Using small cylindrical wire traps (eel traps $90 \mathrm{~cm}$ long by $30 \mathrm{~cm}$ diameter) baited with fish, a total of 109 nearshore locations along the shores of the Bras d'Or Lakes were sampled from August to November 1999 and July-August 2000 (Paul, 2001). Sampling depths were usually 1-2 $\mathrm{m}$, but up to $5 \mathrm{~m}$. Green crabs were found throughout the Lakes, with catch rates in individual traps reaching 50 or more over just $3 \mathrm{~h}$ in several locations. Among the different areas of the Lakes, Whycocomagh Basin had the lowest mean catch rate (1.3 in 3 traps) while St. Peter's Inlet had the highest (51.3 in 3 traps; Fig 12).

Given the apparent sensitivity of green crab larvae to salinities less than 25 (Table III) it is expected that larval survival would be greater in areas such as the Great Bras $d^{\prime}$ Or Channel and the approaches to it, but green crab catch rates in these areas were lower than in the St. Peter's Inlet area (Fig 12). Assuming that the catch rates reflect abundance on the bottom, factors other than salinity (such as bottom habitat and wave exposure) may be necessary to explain green crab distribution in the Lakes.

The effects of green crab on the invertebrate communities of the Bras d'Or Lake are just beginning to be studied. Concern over the effects of predation on oysters is high and studies to determine the sizes of oysters green crab can consume are in progress (Paul, 2001). Green crab will also interact with other species. Cod appear to be eating substantial numbers of green crab based on cod stomach analyses (Lambert, 2001). Since rock crab also inhabit the shallow areas of Bras d'Or Lakes there is likely some competition for food. In addition green crab may prey directly on rock crab (probably those that are smaller) and vice versa. Since rock crab is an important food item for lobsters (Gendron et al., 2001) any change in the abundance of rock crab caused by green crab could affect lobster populations. The options for mitigating the potential effects of green crab include changes to oyster culturing practices to minimize predation, as well as trapping and removal. The latter option is likely to be successful only in very localized areas. There is currently no commercial fishery for green crab in Nova Scotia but there are ongoing efforts to develop markets or to use green crab as bait for other fisheries.

Oysters Oysters (Crassostrea virginica) are probably the single most important species in the Bras d'Or Lakes from the economic and cultural perspectives. Oysters have been harvested for centuries by the Mi'kmaw, and probably since the 1800s by non-native settlers. Oysters are found in Denys Basin, St. Patrick's Channel, Whycocomagh Basin, West Bay, East Bay and St. Peter's Inlet (Fig 7b), where water temperatures increase significantly during the summer. In all locations oysters are generally found in less than a few meters depth. Trawl surveys are not effective in these areas and no oysters were recorded in 1967 or in 1999 - 2000.

The life history and physiology of the eastern oyster makes this species well suited to the Lakes. While low salinities may at times stress oysters (Medcof and Needler, 1941; Bataller et al., 1999), this does not appear to be a major problem. The timing and quantities of oyster settlement in parts of the Bras d'Or Lakes are fairly predictable (Mclsaac, 2000). Oysters spawn when the temperature exceeds $20^{\circ} \mathrm{C}$ for several days, usually in late June to early July. Typically the oysters settle as "spat" in 2-3 weeks (Dept. of Fish. Oceans, 1996; Mclsaac, 2000). Low tidal exchange and currents, coupled with a short planktonic period, ensures high retention of oyster larvae, particularly in semi-enclosed areas such as Gillis Cove. This increases the success of oyster culturists in the collection of spat, but may also result in starvation of young oysters if their collective need for phytoplankton exceeds the local carrying capacity. The type of bottom oysters settle on will affect survival and growth characteristics (Lavoie, 1995). Spat settling on 
the abundant eelgrass within the Lakes may die when the eelgrass is blown ashore in storms; those settling on soft mud will sink and die. The best bottom is a mixture of silt and sand that is hard enough to support the weight of the oyster.

During the 1920s an average of 1512 barrels (each 90.7 kg) of Bras d'Or Lakes oysters were marketed annually (Needler, 1934). As in more recent times, the quantity of oysters collected for food was not recorded. Most $(90 \%)$ of the oysters in the 1920s were taken from the Denys Basin and St. Patrick's Channel areas (Needler, 1936). Currently oysters are harvested from lease and public beds. A survey of oyster distribution in 1990 indicated $85 \%$ of animals were located on leases and $15 \%$ on public beds (Dept. of Fish. Oceans, 1996). About 7\% were in areas closed because of high bacterial counts. The success of oyster populations in the Lakes is affected by natural, social and economic factors. The blue mussel (Mytilus edulis and M. trossulus) is the oyster's main competitor for food and space (Medcof 1961; Fig 1d) and heavy mussel settlement can reduce oyster growth and survival. Mortality due to predators such as the starfish Asterias vulgaris (Drinnan, 1976) and more recently the green crab can be important. Starfish have their greatest effects when oysters are small, as above about $6 \mathrm{~cm}$ in length oysters are immune (Drinnan, 1976). Predation by man is at least as important-overfishing is thought to have caused the decline in the abundance of oysters on the public beds (Mclsaac, 2000). Overfishing of brood stock can also threaten reproduction in enclosed areas.

Challenges for oyster culture in the Lakes include all of the above factors as well as others: reliable seed sources, reductions in oyster grow-out areas due to bacterial contamination, reliable markets (Dennis, 1998) and reductions in market value due to mud blister worms (Medcof, 1961; McGladdery et al., 1993). Spat sources may be affected if blue mussels settle on oyster collectors, reducing the growth and survival of oysters, and increasing sorting costs. Blister worms (Polydora sp., a polychaete) can infest the inside of oyster shells in parts of the Bras d'Or Lakes. The resulting mud blisters are innocuous but can reduce the value of oysters sold in the half-shell trade.

Other bivalves: scallops, mussels, clams, and quahogs Sea scallops Placopecten magellanicus are typically found in tidally well-mixed areas on gravel bottoms. In both the 1967 and 1999-2000 surveys catch rates were low but they were collected mainly in the North Basin, Great Bras d'Or Channel, and St. Andrew's Channel (Figs. $8,9)$. Scallops are occasionally fished with drags in the outer part of the Great Bras d'Or Channel; catches are insignificant relative to commercially fished areas on the Scotian Shelf and the Gulf of Maine (Black et al., 1993). Given the relatively poor tolerance of adults to low salinity (Table III), and the expectation that larvae would be even less tolerant, the reduced salinities of the Lakes must be important in limiting scallop abundance.

Blue mussels (Mytilus edulis) occur throughout the Lakes on harder bottom. In the 1967 trawl survey they were mentioned but not quantified. In the 1999-2000 they were most abundant in St. Peter's Inlet and Bras d'Or Lake (Fig 9). Blue mussel adults are particularly tolerant of low salinities (almost all survive at 5), indicating that low salinities in the Lakes are not an issue (Table III). The 1999-2000 trawl surveys encountered only blue mussels in the Lakes. The horse mussel (Modiolus modiolus) has not been recorded in the Lakes (Table II) but does occur between Carey Pt. and Cape Dauphin. The lack of horse mussels within the Lakes may be related to this species poor tolerance of reduced salinities. Study of the adults indicates $50 \%$ or more will die at 22 (Table III); larvae would presumably be less tolerant. The horse mussel is less capable of regulating cellular volume when challenged with reduced salinities (Gainey, 1994). 
Soft-shell clams Mya arenaria, bar clams Spisula solidissima, razor clams Ensis directus, and quahogs Mercenaria mercenaria have all been reported in the Bras d'Or Lakes (Table II) but there are no documented studies of their distribution. The harvest of these bivalves within the Lakes has been small-scale and primarily for food; currently there is no consistent commercial fishery for these species.

Sea urchins and starfish Sea urchins (Strongylocentrotus droebachiensus) and starfish (mainly Asterias vulgaris) are currently distributed widely in the Bras d'Or Lakes. The survey of traditional knowledge reported sea urchins throughout Bras d'Or Lake, but starfish were not mapped. In the 1999-2000 trawl surveys, sea urchins dominated the invertebrate catch within Bras d'Or Lake including East and West Bays (Fig 9). Many of the sea urchins were small. Starfish were found throughout the Bras d'Or Lakes in abundances considerably greater than any crabs or bivalves (Fig 9).

The relatively high abundances of sea urchins within the Bras d'Or Lake and low abundances in the Great Bras d'Or Channel are unexpected. Laboratory studies indicate sea urchin larvae have low tolerances to low salinities (Table III). As for crustaceans, the adults are more tolerant (Table III) so once the larval stage is completed, lower salinities are less important. There are no available data on the salinity tolerance of Asterias vulgaris. Studies of the role of these potentially important grazers (urchins) and predators (starfish) are needed.

Sea urchins are not harvested within the Bras d'Or Lakes, but some unsuccessful exploratory fishing has occurred (Denny, 2001). Commercial operations depend on high densities of large, well-fed urchins that have a high yield of roe.

\section{Conclusions}

Key features of the Bras d'Or Lakes relevant to the distribution of epibenthic invertebrates are reduced salinities, limited physical exchange with the open coast, diversity of seasonal temperature regimes, and low tidal amplitudes. Published studies of other benthic taxa indicate that warm-water, Boreal-Arctic and Arctic faunas are found in the Lakes, probably because of the diversity of temperature regimes within the Bras d'Or Lakes.

There is still much to be learned about what limits even some well known epibenthic species within the Bras d'Or Lakes. The reduced salinities within the Lakes probably limit the distribution of several species, particularly during the more sensitive larval period. Most laboratory studies of salinity tolerance only document the lethal effects but sublethal effects on growth, behaviour and reproduction probably occur. These more subtle effects are more difficult to document. Species that are most likely adversely affected by the reduced salinities of the Bras d'Or Lakes include rock crab, sea scallops and possibly lobsters. Based on salinity tolerance, other species (green crab, sea urchins) should be more abundant in the more saline parts of the Bras d'Or Lakes but the available distribution data do not show this. Low food availability may be another limiting factor for a variety of Bras d'Or Lakes epibenthic invertebrates, but more study is needed to establish whether this is important.

The extent of lobster movement between the Bras d'Or Lakes and Sydney Bight is not known but the higher frequency of a particular colourmorph in the Lakes suggests some isolation. Lobsters in the Bras d'Or Lakes are much less abundant than on the open coast of Cape Breton Island. Possible reasons include reduced salinity, limited cobble bottom substrate, low food and low egg production. There is anecdotal evidence that lobster abundance in the Lakes is lower now than it was 30 years ago. Current low egg production may be the result of excessive fishing in the past. To better understand 
which factors are most important in limiting lobster abundance in the Bras d'Or Lakes, and the extent of isolation of lobsters in the Lakes, studies are needed of the distribution of all lobster life-history stages, of Bras d'Or Lakes bottom types (using tools such as multibeam bathymetry), and of the health and condition of lobsters.

The eastern oyster appears to be well suited to the areas of the Lakes with warm summer temperatures. The short larval period and semi-enclosed nature of these areas promotes high larval retention. Reduced salinities do not appear to hamper oyster production in a significant manner. The oyster populations in the Bras d'Or Lakes should thrive if innovative approaches can be developed to deal with natural predators (e.g. starfish and the newly arrived green crab), competitors (e.g. blue mussel), and overfishing. Oyster aquaculture would benefit from a reduction in the numbers of areas closed due to high bacterial counts.

The newly arrived green crab may affect a number of species within the Bras d'Or Lakes, but its overall effect on the food web is difficult to predict. Predation on bivalves such as oysters is likely significant, and studies to evaluate and mitigate this effect are needed. The interaction with other crabs, lobsters and other species is more difficult to predict since green crab may act both as a predator and as a food source.

Sea urchins and starfish are both present in considerable abundance in the Bras $d^{\prime}$ Or Lakes. Study of the potentially important roles of these species in structuring the benthic community are warranted. Clearly there is a need for more studies of the distribution and ecology of epibenthic invertebrates within the Bras d'Or Lakes. The adoption of a comparative approach with the open coast of Cape Breton Island would be profitable.

\section{Acknowledgements}

Thanks to the First Nations group at the Unama'ki Institute of Natural Resources (UINR) for encouraging and supporting this work with data for the maps, discussions and technical support. Several people encouraged this work: C. Dennis, T. Lambert, B. Petrie and M. Sinclair. I thank the following people for providing unpublished data or reports used in this paper: T. Lambert, B. Petrie, Kara Paul, T. Johnson, C. Dennis and T. Kenchington. Thanks to A. Reeves and B. Lively for the Bras d'Or Lakes maps. For providing comments on the paper I thank R. Claytor, S. Denny, T. Lambert, R. Lavoie, B. Petrie and two anonymous reviewers. G. Sharp is thanked for marine plant identifications.

\section{References}

Anger, K., Spivak, E. and Luppi, T. 1998. Effects of reduced salinities on development and bioenergetics of early larval shore crab, Carcinus maenas. J. Exp. Mar. Biol. Ecol. 220: 287-304.

Bailey, J., Parsons, J. and Couturier, C. 1996. Salinity tolerance in the blue mussel, Mytilus edulis. Bull. Aquacul. Assoc. Canada 96-3: 74-76.

Bataller, E.E., Boghen, A.D. and Burt M.D. 1999. Comparative growth of the eastern oyster Crassostrea virginica (Gmelin) reared at low and high salinities in New Brunswick, Canada. J. Shellfish Res. 18:107-114.

Bergman, C., Parsons, J. and Couturier, C. 1996. Tolerances of the giant sea scallop, Placopecten magellanicus, to low salinity. Bull. Aquacul. Assoc. Canada 96-3: 62-64 
Bigford, T.E. 1979. Synopsis of biological data on the rock crab, Cancer irroratus Say. NOAA Tech. Rept. NMFS Circ. 426.

Black, W.F. 1976. Aspects of the marine biology of the Great Bras d'Or. IN: The Proceedings of the Bras d'Or Lakes Aquaculture Conference (Ed. G. McKay) College of Cape Breton Press, Sydney. pp. 44-53.

Black, G.A.P., Mohn, R.K., Robert, G. and Tremblay, M.J. 1993. Atlas of the biology and distribution of the sea scallop Placopecten magellanicus and Iceland scallop Chlamys islandica in the Northwest Atlantic. Can. Tech. Rep. Fish. Aquat. Sci. 1915: 40 p.

Bousfield, E.L. and Laubitz, D.R. 1972. Station lists and new distributional records of littoral marine invertebrates of the Canadian Atlantic and New England regions. Nat. Mus. Nat. Sci. Ottawa, Publications in Biological Oceanography no. 5, 51 pp.

Bousfield, E.L. and Thomas, M.L.H. 1975. Postglacial changes in distribution of littoral marine invertebrates in the Canadian Atlantic region. Proc. N.S. Inst. Sci. 27, Supplement 3:47-60.

Charmantier, G. and Charmantier-Daures, M. 1991. Ontogeny of osmoregulation and salinity tolerance in Cancer irroratus; elements of comparison with $C$. borealis (Crustacea, Decapoda). Biol. Bull. 180:125-134.

Charmantier, G., Charmantier-Daures, M., Bouaricha, N., Thuet, P., Aiken, D.E. and Trilles, J.-P. 1988. Ontogeny of osmoregulation and salinity tolerance in two decapod crustaceans: Homarus americanus and Penaeus japonicus. Biol. Bull. 175:102-110.

Dennis, C. 1998. The Bras d'Or Lakes oyster industry. J. Shellfish Res. 17:1298 (abstract).

Denny, S. 2001. (Unama'ki Institute of Natural Resources, Eskasoni, N.S.) Personal communication.

Department of Fisheries and Oceans. 1996. Cape Breton American Oyster. DFO Atlantic Fisheries Stock Status Report 96/124E.

Drinnan, R.E. 1976. Oysters - disease, predation and competitors. IN: The Proceedings of the Bras d'Or Lakes Aquaculture Conference (Ed. G. McKay). College of Cape Breton Press, Sydney. pp. 125-129.

Elner, R.W. 1981. Diet of green crab Carcinus maenas (L.) from Port Hebert, southwestern Nova Scotia. J. Shellfish Res. 1:89-94.

Ennis, G.P. 1995. Larval and postlarval ecology. IN: Biology of the lobster Homarus americanus (Ed. J.R. Factor.) Acedemic Press, San Diego. pp. 23-46.

Eskasoni Fish and Wildlife Commission and Dept. of Fisheries and Oceans. 1996. The Bras d'Or Lake Coastal Resources Mapping Project, managed by the Unama'ki Institute of Natural Resources (UINR), 4123 Shore Rd. Eskasoni, Nova Scotia B0A1J0. Unpublished maps.

Fournier, J.A. and Pocklington, P. 1984. The sublittoral polychaete fauna of the Bras d'Or Lakes, Nova Scotia, Canada. IN Proc. First Int. polychaete conference, Sydney (Ed. P.A. Hutchings). The Linnean Society of New South Wales, pp 254-278.

Gainey, L.F. Jr. 1994. Volume regulation in three species of marine mussels. J. Exp. Mar. Biol. Ecol. 181:201-211.

Gendron, L., Fradette, P. and Godbout, G. 2001. The importance of rock crab (Cancer irroratus) for growth, condition and ovary development of adult American lobster (Homarus americanus). J. Exp. Mar. Biol. Ecol. 262:221-241.

Harding, G.C., Pringle, J.D., Vass, W.P., Pearre, S. Jr. and Smith, S.J. 1987. Vertical distribution and daily movements of larval lobsters Homarus americanus over Browns Bank, Nova Scotia. Mar. Ecol. Prog. Ser. 41: 29-41. 
Jones, M. 2001. (Dept. of Biology, Dalhousie University, Halifax, N. S.) Personal communication.

Jury, S.H., Kinnison, M.T., Huntting Howell, W. and Watson, W.H. 1994. The effects of reduced salinity on lobster (Homarus americanus Milne-Edwards) metabolism: implications for estuarine populations. J. Exp. Mar. Biol. Ecol. 176: 167-185.

Kennish, M.J. 1990. Ecology of estuaries. Volume II, Biological aspects. CRC Press, Boca Raton, Fla. p. 242.

Lambert, T.C. 2001. (Dept. of Fisheries and Oceans, Halifax, N. S.) Personal Communication.

Lambert, T.C. 2002. Overview of the ecology of the Bras d'Or Lakes with emphasis on the fish. Proc. N.S. Inst. Sci. 42:67-100

Langeley, J. 2000. (Fisherman, Port Hawkesbury, N. S.) Personal communication.

Lavoie, R.E. 1995. Culture of the American oyster Crassostrea virginica. IN Cold water aquaculture in Atlantic Canada (2 ${ }^{\text {nd }}$. edition). (Ed. A.D. Boghen). pp. 191-224.

MacDonald, K.F. 1968. Fish population assessment, Bras d'Or Lake, Cape Breton Island. N.S. Dept. Fish., Resource Development Div., Pictou, 16p.

Mclsaac, A. 2000. Eskasoni First Nation launches the Malagawatch Oyster. Shellfish World 1:8-9.

McGladdery, S.E., Drinnan, R.E. and Stephenson, M.F. 1993. A manual of parasites, pests and diseases of Canadian Atlantic bivalves. Can. Tech. Rept. Fish. Aquat. Sci. 1931: $121 \mathrm{p}$.

McLachlan, J. and Edelstein, T. 1971. Investigations of the marine algae of Nova Scotia. IX. A preliminary survey of the flora of Bras d'Or Lake, Cape Breton Island. Proc. N.S. Inst. Sci. 27:11-22.

McLeese, D.W. 1956. Effects of temperature, salinity and oxygen on the survival of the American lobster. J. Fish. Res. Board Can. 13: 247-272.

Medcof, J.C. 1961. Oyster farming in the Maritimes. Bull. Fish. Res. Board Can. 131: 158 p.

Medcof, J.C. and Needler, A.W.H. 1941. The influence of temperature and salinity on the condition of oysters (Ostrea virginica). J. Fish. Res. Board Can. 5: 253-257.

Morgan, S.G. 2000. The larval ecology of marine communities. IN: Marine community ecology (Eds. M.D. Bertness, S.D., Gaines, and H.E. Hay). Sinauer Associates, Ma. pp. 159-181.

Needler, A.W.H. 1934. Oysters in the Bras d'Or Lakes, Cape Breton. Fish. Res. Board Can. Manuscript Rept. of the Biol. Stations No. 153B. 6 p.

Needler, A.W.H. 1936. Proposals for an oyster culture policy in Cape Breton. Fish. Res. Board Can. Manuscript Rept. of the Biol. Stations No. 153A. 8 p.

Palma, A.T., Steneck, R.S. and Wilson, C.J. 1999. Settlement-driven, multiscale demographic patterns of large benthic decapods in the Gulf of Maine. J. Exp. Mar. Biol. Ecol. 241:107-136.

Paul, K. 2001. (Unama'ki Institute of Natural Resources, Eskasoni, N. S.) Personal communication.

Petrie, B. 2001. (Dept. of Fisheries and Oceans, Halifax, N. S.) Personal Communication.

Petrie, B. and Bugden, G. 2002. The physical oceanography of the Bras d'Or Lakes. Proc. N.S.. Sci. 42:11-38

Pierce, S.K. 1970. The water balance of Modiolus (Mollusca: Bivalvia: Mytilidae): osmotic concentrations in changing salinities. Comp. Biochem. Physiol. 36: 521-533.

Pohle, G.W. 1990. A guide to decapod crustacea from the Canadian Atlantic: Anomura and Brachyura. Can. Tech. Rept. Fish. Aquat. Sci. 1771: iv + 30 P. 
Roller, R.A. and Stickle, W.B. 1994. Effects of adult salinity acclimation on larval survival and early development of Strongylocentrotus droebachiensis and Strongylocentrotus pallidus (Echinodermata: Echinoidea). Can. J. Zool. 72: 1931-1939.

Scarratt, D.J. 1973. Abundance, survival, and vertical and diurnal distribution of lobster larvae in Northumberland Strait, 1962-63, and their relationships with commercial stocks. J. Fish. Res. Board Can. 30:1819-1824.

Shumway, S.E. 1996. Natural environmental factors. IN The eastern oyster Crassostrea virginica. (Eds. V.S. Kennedy,. R.I.E. Newell, and A.F. Eble). Maryland Sea Grant College, College Park, Maryland, pp. 467-513.

Stevens, S. 1993. Bras d'Or Lakes lobster population study. Unpublished manuscript, Mi'kmaq Aboriginal Fisheries Services. 63. p.

Strain, P.M. and Yates, P.A. 2002. The chemical oceanography of the Bras d'Or Lakes. Proc. N.S. Inst. Sci. 42:39-66

(Received 1March 2002) 